\title{
A North American Arctic Aerosol Climatology using Ground-Based Sunphotometry
}

\author{
AMADOU I. BOKOYE ${ }^{1,2}$ ALAIN ROYER, ${ }^{1}$ N.T. O’NEILL ${ }^{1}$ and L.J. BRUCE McARTHUR ${ }^{3}$
}

(Received 19 July 2000; accepted in revised form 28 September 2001)

\begin{abstract}
The Arctic is known as a key area for the detection of climate changes and atmospheric pollution on a global scale. In this paper we describe a new Canadian sunphotometer network called AEROCAN, whose primary mandate is to establish a climatology of atmospheric aerosols. This network is part of AERONET, the worldwide federated sunphotometer network managed by the NASA Goddard Space Flight Center. The potential of sunphotometer data from the AERONET/AEROCAN network for monitoring of Arctic aerosols is illustrated, using examples of the multiyear variation of aerosol optical properties and atmospheric precipitable water vapour content at some stations, and in particular at Bonanza Creek, Alaska since 1994. Despite its sparse spatial density, the network represents an important tool for monitoring the spatio-temporal variation of Arctic aerosols. It also represents an important source of independent aerosol data, which we feel should be further developed in northern areas to improve our understanding of how atmospheric aerosols influence global climate.
\end{abstract}

Key words: aerosols, sunphotometer, aerosol optical depth

RÉSUMÉ. L'Arctique est reconnu comme une région clé pour la détection des changements climatiques et de la pollution atmosphérique à l'échelle planétaire. Cet article présente un nouveau réseau canadien de photomètres solaires (AEROCAN) dont le mandat principal est d'établir une climatologie des aérosols atmosphériques. Ce réseau est intégré au réseau fédéré mondial de photomètres solaires AERONET géré par le Centre des vols spatiaux Goddard de la NASA. Le potentiel des données héliophotométriques générées par le réseau AERONET/AEROCAN pour la surveillance des aérosols dans l'Arctique est illustré à l'aide d'exemples de la variation pluriannuelle des paramètres optiques des aérosols et du contenu en vapeur d'eau atmosphérique précipitable à diverses stations, en particulier à Bonanza Creek (Alaska) depuis 1994. Malgré sa faible densité spatiale, le réseau représente un outil important pour la surveillance de la variation spatio-temporelle des aérosols arctiques. Il représente en outre une source majeure de données indépendantes sur les aérosols, données dont la provenance devrait, selon nous, englober les régions boréales afin que nous ayons une meilleure compréhension de l'influence des aérosols atmosphériques sur le climat de la planète.

Mots clés: aérosols, photomètre solaire, épaisseur optique des aérosols

\section{ARCTIC AEROSOLS AND CLIMATE IMPACT}

Aerosol research in the last few decades (Shaw, 1975a, 1976; Blanchet, 1989, 1991; Gernandt et al., 1996; Herber et al., 1996; Wessel et al., 1997; Becker et al., 1999) has shown how the systematic monitoring of these particles can lead to a better understanding of our climate and the complex processes influencing the earth's atmosphere. Aerosol effects include the direct backscattering of incident solar radiation towards space and the indirect effect of aerosols, acting as cloud droplet nucleation centres, on the chemical, thermodynamic, and optical properties of clouds. Both of these effects lead to variations in the radiation budget of the earth-atmosphere system. Arctic aerosols may also reduce visibility in the atmosphere (Mitchell, 1957).

The Arctic, which covers about 14 million $\mathrm{km}^{2}$, has an important impact on climate. During winter and spring, the area has increased albedo because of snow cover and ice, along with relatively high aerosol loading (Shaw, 1982;
Barrie, 1986). Incident solar energy is backscattered away from the earth and acts as a natural cooling mechanism for this area. The significant decline in sea ice area and thickness observed in the Arctic over the past few decades is generally attributed to greenhouse gases that trap the infrared radiation emitted by the ground (Overpeck et al., 1997). Computerized general circulation models of the atmosphere project that future greenhouse warming will occur more intensely over the Arctic than over any other part of the planet, largely because melting snow and ice will replace bright surfaces with darker tundra and open water surfaces, decreasing the albedo and reflected sunlight from the Arctic. A direct consequence will be an accelerated warming trend (Ledley and Pfirman, 1997; AGU, 1998).

From March to May, Arctic aerosols can have a net positive radiative forcing (Blanchet and Girard, 1994) as opposed to the "whitehouse" aerosol effects shown on a global basis (Reader and Boer, 1998). In contrast, the

\footnotetext{
${ }^{1}$ Centre d'Applications et de Recherches en Télédétection (CARTEL), Université de Sherbrooke, Sherbrooke, Quebec J1K 2R1, Canada

${ }^{2}$ Corresponding author: abokoye@ courrier.usherb.ca

${ }^{3}$ Meteorological Service of Canada, 4905 Dufferin Street, Downsview, Ontario M3H 5T4, Canada

(C) The Arctic Institute of North America
} 
enhanced depletion of water vapour from the cold Arctic troposphere that may be induced by anthropogenic aerosols during winter could lead to greater infrared cooling and therefore explain the observed decrease in Arctic surface temperatures over the last four decades (Kahl et al., 1993). According to Blanchet and Girard (1994), the warming/cooling trend depends upon the dehydration rate of the air. Atmospheric water vapour interacts with Arctic haze particles coated by anthropogenic sulphuric acid (Bigg, 1980; Barrie, 1986) through a complex aerosolcloud-precipitation-radiation process.

Considerable atmospheric research activity is devoted to studies related to Arctic aerosols and their impact on the regional or global climate. In the next section we will demonstrate the utility of passive remote sensing (sunphotometry) as a means of monitoring the variations of Arctic aerosols and climate changes. Our understanding of the impact of aerosols and water vapour on the local and global climate suffers from the absence of long-term observational data on aerosol optical properties and atmospheric water vapour content (especially in the Canadian context). Parameters such as aerosol optical depth, aerosol size distribution, and single scattering albedo may improve climatic models by providing robust validation data.

\section{ARCTIC AEROSOL CHARACTERIZATION}

Aerosol Optical Depth (AOD) is a useful parameter for characterizing the atmosphere in terms of columnintegrated aerosol density. Major contributions to Arctic haze characterization through the AOD parameter can be attributed to Holmgren et al. (1974), Shaw (1982), Freund (1983), Heintzenberg (1989), Herber et al. (1991, 1996, 1997), Leiterer et al. (1992), and Weller et al. (1998). Shaw and Khalil (1989) in their publication on Arctic haze suggested a potential pollution-derived climate impact in the Arctic. Optical measurements have shown that the components of the northern polar atmosphere undergo a strong and repeatable annual variation, with a maximum mass loading between February and April (Barrie, 1986; Smirnov et al., 1996). It is well known that the jet stream can carry air pollution from mid-latitude Eurasia into the Alaskan Arctic. Some studies in Alaska have revealed that aerosol particles responsible for such air pollution have their origin outside Alaska (Stonehouse, 1986; Tyson, 1990). The seasonal variation in AOD at Resolute in the Canadian Arctic, as reported by McGuffie et al. (1985), is similar to the variation that Shaw and Khalil (1989) reported for Alaska. A mean AOD value of 0.1 at the standard reference wavelength of $500 \mathrm{~nm}$ was observed from March to May. This value decreased to less than $0.02 \mathrm{~nm}$ in summer.

The vertical distribution and general physical properties of Arctic haze aerosols are also very important factors in understanding aerosol transport climatology. Shaw (1975b), Hansen and Rosen (1984), Schnell and Raatz
(1984), Hoff (1988) and Nagel et al. (1998) were able to infer certain mechanisms related to the vertical movement of Arctic haze particles from the analyses of Lidar vertical profiles. Carlson (1981), Shaw (1981), and Iversen (1984) studied the transport mechanisms of Arctic aerosols, while Hoff et al. (1983) and Shaw (1983) investigated Arctic aerosol size distributions.

A general consensus on the need for systematic and coherent monitoring of aerosol vertical loading variations has led to development of a number of networks throughout the globe. The most important of these networks is the NASA worldwide federated network of sunphotometers (AERONET, for Aerosol Robotic Network), which includes the Canadian subnetwork (AEROCAN).

\section{AERONET/AEROCAN PROJECT}

The NASA Goddard Space Flight Center (GSFC) AERONET sunphotometer network is described in detail by Holben et al. (1998). AEROCAN's mission is to acquire sufficient spatio-temporal data to permit the development of a Canadian climatology for aerosol optical properties and derived particle-size parameters (Bokoye et al., 2001). This climatology is targeted towards atmospheric correction applications in remote sensing; validation of aerosol dynamics in climatological models, such as the Northern Aerosol Regional Climate Model (NARCM) (Barrie and Blanchet, 1996); and validation of aerosol parameters derived from satellite inversions.

\section{Instrumentation and Data Acquisition System}

The main component of the AERONET/AEROCAN network is the CIMEL ${ }^{\mathrm{TM}}$ CE-318 sunphotometer. This instrument is a multi-wavelength, automatic sun/sky radiometer that measures atmospheric spectral transmission and sky radiance in the almucantar (sky scanning at a constant zenithal angle) and principal plane (sky scanning at a constant azimuthal angle) using a combination of eight ion-assisted deposition interference filters: $1020,870,670$, $500,440,380,340$ for the aerosol channels and $940 \mathrm{~nm}$ for the water vapour of the total atmospheric column. The sky radiance measurements are limited to $1020,870,670$, and $440 \mathrm{~nm}$ channels. The filters are located in a filter wheel, which is rotated by direct drive stepping. The CE-318 sunphotometer is composed of an optical head, an electronic box, and a robot equipped with two step-by-step motors for azimuth/zenith motion controlled by a microprocessor. The optical head has two collimators, each $33 \mathrm{~cm}$ long: the sun collimator (without lens) and the sky collimator (with lenses). Both the collimators have $1.2^{\circ}$ field-of-view (FOV) and were designed for $10^{-5}$ straylight rejection for measurements of the aureole $3^{\circ}$ from the sun. They are also protected by a quartz window, allowing compensation for any temperature dependence in the silicon detector. The sun tracking is made from an evaluation 
of the solar altitude and a four-quadrant detector based on the measurement of maximum irradiance for a precise position (accuracy better than $0.1^{\circ}$ ). The system allows real-time data acquisition and motion control. In automatic mode, a wet sensor detects precipitation and forces the instrument to the stop position. A thermistor measures the temperature of the detector, allowing compensation for any temperature dependence in the silicon detector. Solar transmission measurements are made every 15 minutes for air masses with values between 1.7 and 7 . Note that the air mass is approximately equal to the secant of the zenith angle (that angle from directly overhead to a line intersecting the sun). The air mass indicates the length of the path that solar radiation travels through the atmosphere. An air mass of 1 means that the sun is directly overhead and the radiation travels through one atmosphere (thickness). Sky measurements are made at every hour in the previous range and at specific air mass values $(4,3,2$, and 1.7$)$. The data can be transferred from the memory of the sunphotometer to a Data Collection Systems (DCS), and from there to one of three geostationary satellites: the Geostationary Environment Satellite (GOES), the European weather satellite (METEOSAT), or the Geostationary Meteorological Satellite (GMS). The GOES west satellite is assigned to AEROCAN sites. AEROCAN data are transmitted to a ground-receiving centre and then transmitted to the AERONET office at NASA/GSFC for processing.

\section{Maintenance Procedures, Calibration, and Data Processing}

The site managers maintain the northern AERONET/ AEROCAN sites, and AERONET/AEROCAN coordinators perform a remote check of the instruments daily, from transmission reports updated every two hours on the AERONET Web site. These reports describe the different measurement sequences of the CIMEL ${ }^{\mathrm{TM}}$ multi-angular sunphotometer and also allow the remote identification of clock drift, power supply, or mechanical problems from error codes. Thus, regular checks and troubleshooting instructions are sent to site managers for quick intervention. However, the measurements are more difficult in winter, taking into account the rigor of meteorological conditions in Arctic areas.

Since sunphotometer measurements may be affected by several types of error, some uncertainties exist in the parameters retrieved. Potential sources of error include $\mathrm{V}_{\mathrm{o}}(\lambda)$ (sunphotometer calibration constant for a given wavelength $\lambda$ ) calibration, electronic failure, filter degradation, solar misalignment, detector temperature-dependence, and pressure variation effects on the assumed values of Rayleigh optical depths. Significant effort has been made in sunphotometry to quantify and analyze these errors. The principal source of error is, arguably, inaccuracy in determining the $\mathrm{V}_{\mathrm{o}}(\lambda)$ coefficients (Reagan et al., 1986; Soufflet et. al., 1992; Forgan, 1994; Schmid and Wehrli, 1995; Schmid et al., 1998; Bigelow and Slusser, 2000; Porter et. al., 2000; Slusser et al., 2000). The $\mathrm{V}_{\mathrm{o}}(\lambda)$ calibration errors depend mainly on the stability of the atmosphere during the acquisition of Langley plot data. For example, a $4 \%$ calibration error yields an uncertainty of 0.02 in AOD at a solar airmass of 2. The uncertainties relating to the calibration and the reference data used to constrain the algorithms, inputs, corrections, and models in computing AOD, PWVC (precipitable water vapour content), and sky radiance inversions are reported in Holben et al. (1998). The variations of $V_{o}(\lambda)$ from calibration to calibration can often be linked to ageing of the optical train components (most notably degradation of the filters). The AERONET reference sunphotometers are checked every week as part of the calibration methodology: an example of $\mathrm{V}_{0}(\lambda)$ variation for one of these devices during a oneyear period can be found in Holben et al. (2000). The average coefficient of variation of $\mathrm{V}_{\mathrm{o}}(\lambda)$ (standard deviation/mean) is $0.3 \%$ to $0.5 \%$ for the aerosol channels and about $2 \%$ to $4 \%$ for the $940 \mathrm{~nm}$ channel.

The spectral variation of the AOD accuracy of the solar channels is nominally \pm 0.01 or better for $\lambda$ greater than $440 \mathrm{~nm}$ and \pm 0.02 or better for the two ultraviolet (UV) channels at 380 and $340 \mathrm{~nm}$. Eck et al. (1999) computed the combination of calibration uncertainties and uncertainty in ozone (due to seasonality and atmospheric dynamics) and Rayleigh optical depth (due to the variability in air pressure), for optical air mass 1 , in the manner of Russell et al. (1993). The resulting estimated total AOD uncertainty is $0.01-0.02$ for field instruments (spectrally dependent, with the higher errors in the UV range), and approximately 0.002 to 0.009 for reference instruments. Schmid et al. (1999) compared AOD values derived from four different solar radiometers (including an AERONET sun/sky sunphotometer) operating simultaneously together in a field campaign and found that the AOD values from 380 to $1020 \mathrm{~nm}$ agreed to within $0.015 \mathrm{rms}$ (root mean square). This value is similar to the estimated level of uncertainty in AOD retrieval for field instruments. The $1020 \mathrm{~nm}$ band showed a significant temperature variation $\left(0.25 \%\right.$ per ${ }^{\circ} \mathrm{C} / \pm 0.05 \%$ per $\left.{ }^{\circ} \mathrm{C}\right)$, warranting correction to a reference temperature in the processing. The sky channels of the instruments are calibrated, using an absolutely calibrated integrating sphere, to a radiance accuracy of $\pm 5 \%$ or better (Holben et al., 1998). A dark current subtraction is applied to each channel before processing the data records. About five years of AOD quality assurance experience with the calibration procedure provides reasonable confidence that the error budget is largely maintained at the nominal values for newly calibrated instruments and that for field instruments, the AOD error is better than \pm 0.02 in the visible wavelength region.

The mean uncertainty of the Angstrom coefficient $(\alpha)$, computed from the linear regressions applied to each AOD spectrum (assuming no error in AOD) and using all the instantaneous data for each AEROCAN site, ranges between \pm 0.13 and \pm 0.18 depending on the site. Halthore et al. (1997) discussed the determination of atmospheric precipitable water vapour content (PWVC) using the 


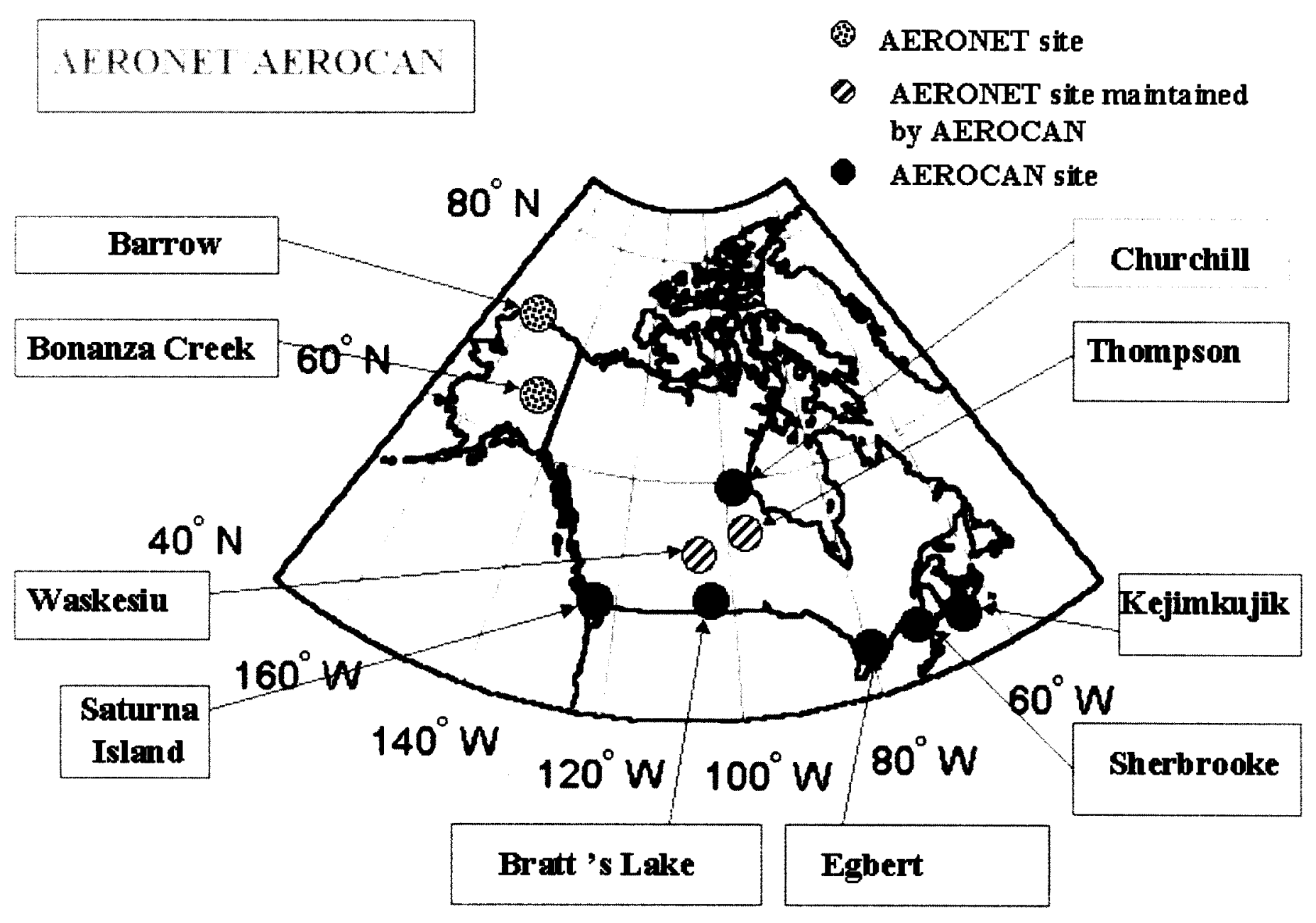

FIG. 1. Current sunphotometer locations for Canada and Alaska of the AERONET/AEROCAN network (Canadian sunphotometer network/NASA worldwide sunphotometer network).

CIMEL ${ }^{\mathrm{TM}}$ sunphotometer and the associated errors. The authors found that the $940 \mathrm{~nm}(10 \mathrm{~nm}$ bandwidth) generally used for PWVC retrieval yielded results with less than $1 \%$ variability under various atmospheric conditions. The PWVC precision depends strongly on the water vapour transmittance model considered in the above spectral band (Schmid et al., 1996). The influence of measurement errors on aerosol microphysical properties retrieved from extinction and sky radiance data are discussed in Dubovik et al. (2000).

Output products include spectral AOD, Angstrom coefficient, particle size distribution, refractive index and single scattering albedo, and atmospheric precipitable water vapour content (PWVC). Three levels of data are available from the public website: Level 1.0 (unscreened), Level 1.5 (cloud-screened), and Level 2.0 or Quality Assured level, limited to some stations (Smirnov et al., 2000). The AEROCAN group performs further processing and statistical data analysis as part of the development of a Canadian climatology and a Canadian database. Our additional criterion was to reject $\alpha$ values corresponding to an rms linear regression error greater than $30 \%$. This database can be consulted upon request.
The AEROCAN network currently includes eight sunphotometers distributed across a variety of Canadian sites chosen in order to obtain a diverse sampling of continental, maritime, and Arctic aerosols (Fig. 1). The eighth sunphotometer of the AEROCAN network was installed in May 2000 at Churchill, Manitoba $\left(58^{\circ} 43^{\prime} \mathrm{N}\right.$, $94^{\circ} 07^{\prime} \mathrm{W}$ ), on the western shore of Hudson Bay. The monitoring of atmospheric aerosols in this area, which serves as a natural laboratory for several climate change projects, will help to determine the amount of local versus transported anthropogenic aerosols in the region and the role sea-salt particulates play in the radiation budget for the Bay. Two other operational sites that measure aerosol optical properties are the AERONET sites at Barrow, Alaska $\left(71^{\circ} 18^{\prime} \mathrm{N}, 156^{\circ} 39^{\prime} \mathrm{W}\right)$, on the coast of the Beaufort Sea, and Bonanza Creek, Alaska (64 $\left.44^{\prime} \mathrm{N}, 148^{\circ} 18^{\prime} \mathrm{W}\right)$, located near Fairbanks in the middle of a mixed coniferous/deciduous forest. Within relatively pristine airsheds, these two sites cannot necessarily be considered representative of the entire Arctic. Barrow, representing north coast Alaska, should provide information on trans-Arctic aerosols from Russia during the spring and possibly seasalt from onshore breezes during the summer period when 
TABLE 1. Summer (June-August) mean values of Aerosol Optical Depth at $500 \mathrm{~nm}$ (AOD500) for a) AERONET/AEROCAN sites and b) past records from the literature. Values in (a) were obtained from the geometric mean, and the number of observations is given in parentheses. Values in Table (b) are expressed using the arithmetic mean.

a) AERONET/AEROCAN summer (June, July, August) mean values

\begin{tabular}{|c|c|c|c|c|c|}
\hline Station & Coordinates & AOD500 & $95 \% \mathrm{CI}$ & Years & Data source \\
\hline Barrow & $71^{\circ} 18^{\prime} \mathrm{N}, 156^{\circ} 39^{\prime} \mathrm{W}$ & $0.064(550)$ & $0.061-0.067$ & $1997-2000$ & AERONET \\
\hline Bonanza Creek & $64^{\circ} 44^{\prime} \mathrm{N}, 148^{\circ} 18^{\prime} \mathrm{W}$ & $0.071(4850)$ & $0.070-0.072$ & $1994-2000$ & AERONET \\
\hline Churchill & $58^{\circ} 43^{\prime} \mathrm{N}, 94^{\circ} 07^{\prime} \mathrm{W}$ & $0.064(521)$ & $0.061-0.066$ & 2000 & AEROCAN \\
\hline Thompson & $55^{\circ} 47^{\prime} \mathrm{N}, 97^{\circ} 50^{\prime} \mathrm{W}$ & $0.114(4574)$ & $0.111-0.117$ & $1994-98$ & AERONET/AEROCAN \\
\hline \multirow[t]{2}{*}{ Waskesiu } & $53^{\circ} 55^{\prime} \mathrm{N}, 106^{\circ} 04^{\prime} \mathrm{W}$ & $0.095(7411)$ & $0.093-0.096$ & $1994-99$ & AERONET/AEROCAN \\
\hline & Total northern Canada and Alaska & $0.09(17906)$ & $0.080-0.100$ & $1994-99$ & \\
\hline
\end{tabular}

b) Shaw (1982) and Freund (1983) summer (June, July, August) mean values

\begin{tabular}{|c|c|c|c|c|c|}
\hline Station & Coordinates & AOD500 & $\mathrm{SD}$ & Year & Data source \\
\hline Alert & $82^{\circ} 50^{\prime} \mathrm{N}, 62^{\circ} 18^{\prime} \mathrm{W}$ & 0.08 & 0.02 & 1978 & Freud, 1983 \\
\hline Barrow & $71^{\circ} 18^{\prime} \mathrm{N}, 156^{\circ} 39^{\prime} \mathrm{W}$ & 0.06 & 0.03 & 1978 & Shaw, 1982 \\
\hline Fairbanks & $64^{\circ} 54^{\prime} \mathrm{N}, 147^{\circ} 54^{\prime} \mathrm{W}$ & 0.09 & 0.05 & 1978 & Shaw, 1982 \\
\hline \multirow[t]{2}{*}{ Inuvik } & $68^{\circ} 18^{\prime} \mathrm{N}, 133^{\circ} 30^{\prime} \mathrm{W}$ & 0.09 & 0.03 & $1978-80$ & Freud, 1983 \\
\hline & Total northern Canada and Alaska & 0.08 & 0.03 & $1978-80$ & \\
\hline
\end{tabular}

the ocean is ice-free. Local aerosols emanating from the forest surroundings during late spring and summer may well influence Bonanza Creek. Neither site is necessarily representative of the tundra conditions found throughout the more continental Canadian Arctic. Several Canadian sites are therefore being considered to enhance the AERONET network as part of AEROCAN. Two of the sites under consideration are Eureka $\left(80^{\circ} \mathrm{N}, 85^{\circ} 24^{\prime} \mathrm{W}\right)$, already part of the Network for the Detection of Stratospheric Change (NDSC), and Cambridge Bay $\left(69^{\circ} 05^{\prime} \mathrm{N}\right.$, $105^{\circ} \mathrm{W}$ ), on the southern shore of Victoria Island, an upper-air station of the Meteorological Service of Canada.

\section{OBSERVATIONS}

\section{Northern Canada and Alaska}

Table 1 shows mean summer monthly values of AOD500 (AOD at $500 \mathrm{~nm}$ wavelength) for northern AEROCAN/ AERONET sites (Table 1a) compared to the means of the same parameter for historical records (Table $1 b$ ) reported about 10 years earlier (Shaw, 1982; Freund, 1983). The mean AOD500 values were evaluated from instantaneous values using the geometric mean for the AERONET/ AEROCAN sites in Table 1a, whereas for the historical records in Table $1 b$ they are expressed with the arithmetic mean. The use of the geometric mean is justified because the overall AOD500 values reported are typically distributed as a lognormal function (O'Neill et al., 2000). The geometric mean is a better estimate than the arithmetic mean of the central values, as it is less influenced by episodic high values not representative of the mean background. The parameter CI represents the $95 \%$ confidence interval for the geometric mean. This range of values was calculated using the standard error of the mean (SEM), that is, the standard deviation divided by the square root of the number of observations. In fact, when the distribution is normal or approximately normal, and the sample size is larger than 30, then there is $95 \%$ confidence that the population mean is located in the interval mean \pm 1.96 SEM. For the geometric mean, the lower and upper confidence limits are obtained by considering the antilog of the above limits. The historical data shown in Table $1 \mathrm{~b}$ were recorded "manually" under clear sky conditions. The parameter SD (standard deviation) in the table refers to the classical standard deviation on a linear scale in AOD. The Thompson site, which is subject to the influences of forest fires (Markham et al., 1997), shows the highest mean AOD500 values, whereas the Barrow and Churchill sites reveal the lowest values. The multiyear average summer value of 0.09 for the northern Canadian and Alaskan sites (Table 1a) is not significantly different from the 0.08 value for the period 1978-80 (Table 1b).

Table 2 lists the mean values of AOD500, Angstrom coefficient $(\alpha)$, and total integrated atmospheric precipitable water vapour content (PWVC) in $\mathrm{g} \mathrm{cm}^{-2}$ corresponding to all observations for the northern Canadian and Alaskan sites. The Angstrom exponent $(\alpha)$ is obtained by applying a least squares fit to the measured optical thickness at the 440, 500, 670, and $870 \mathrm{~nm}$ wavelengths. This parameter is sensitive to aerosol size distribution, with values typically ranging from greater than 2 (small particles) to slightly less than zero (large particles). It is assumed to be constant throughout the spectrum despite its weak spectral dependence (see e.g., O'Neill et al., 2001). PWVC is inferred from direct solar radiation measurements at the $940 \mathrm{~nm}$ wavelength (Halthore et al., 1997). We found a mean AOD500 value of 0.079 for the five northern Canadian and Alaskan sites (Table 2). The 
TABLE 2. AERONET/AEROCAN (Canadian sunphotometer network/NASA worldwide sunphotometer network) mean values of Aerosol Optical Depth at $500 \mathrm{~nm}$, expressed using the geometric mean and the $95 \%$ confidence interval (CI); Angstrom coefficient $\alpha$ and precipitable water vapour content (PWVC in $\mathrm{g} \mathrm{cm}^{-2}$ ), both expressed with the arithmetic mean. These means correspond to all the observations available for each site.

\begin{tabular}{|c|c|c|c|c|c|c|c|c|c|}
\hline Station & $\mathrm{ND}^{1}$ & $\mathrm{NO}^{1}$ & AOD500 & $\mathrm{CI}$ & $\alpha$ & SD & PWVC & SD & Year \\
\hline Barrow & 86 & 635 & 0.068 & $0.064-0.071$ & 1.341 & 0.557 & 1.585 & 0.521 & $1997-2000$ \\
\hline Bonanza Creek & 637 & 8406 & 0.067 & $0.065-0.068$ & 1.327 & 0.594 & 1.328 & 0.582 & $1994-2000$ \\
\hline Churchill & 45 & 584 & 0.071 & $0.068-0.074$ & 1.579 & 0.520 & 1.518 & 0.602 & 2000 \\
\hline Thompson & 454 & 6639 & 0.101 & $0.098-0.103$ & 1.659 & 0.700 & 1.647 & 0.638 & $1994-98,2000$ \\
\hline Waskesiu & 717 & 12355 & 0.080 & $0.079-0.081$ & 1.424 & 0.485 & 1.616 & 0.591 & $1994-2000$ \\
\hline Total northern Canada and Alaska & 1939 & 28619 & 0.079 & $0.078-0.080$ & 1.451 & 0.589 & 1.536 & 0.614 & $1994-2000$ \\
\hline
\end{tabular}

${ }^{1} \mathrm{ND}=$ number of days; $\mathrm{NO}=$ number of observations.

Angstrom coefficient mean value is $1.45 \pm 0.59$ for northern Canadian and Alaskan sites. This mean value is slightly higher than the most probable value 1.3 (Holben et al., 2000), which is a typical value assumed for mid-latitude rural conditions. Such values should be linked to the potential influence of Eurasian pollution transported to the Arctic, as suggested by Shaw (1981), or to the potential transport of burning biomass or anthropogenic aerosols or both, as described by Jaffrezo et al. (1999).

A mean PWVC value of $1.54 \pm 0.61 \mathrm{~g} \mathrm{~cm}^{-2}$ was computed for northern Canada and Alaska from the selected sites. This mean is similar to the summer values reported by Gueymard (1994). The monthly means trend is similar to the findings of Serreze et al. (1995), who analyzed atmospheric water vapour trends from 1974 to 1991 across 77 stations at $70^{\circ} \mathrm{N}$ latitude. A relative site-to-site stability of this parameter can also be noted.

\section{A Case of Multiyear Variation: Bonanza Creek Site}

To determine the type of information that could be obtained from such types of stations we analyzed the data from the Bonanza Creek CIMEL ${ }^{\mathrm{TM}}$. The season-to-season and month-to-month records of aerosol optical properties and the atmospheric water vapour content each year allowed us to build a climatology that is very useful for assessing long-term climate changes. The expansion of the network will allow us to increase the database for Arctic regions. The new Churchill site has been operational since April 2000, and financial support has been acquired for another sunphotometer, which will soon be installed in the Canadian Arctic.

Figure 2 shows AOD500 seasonal means and their corresponding standard deviation variations for the Bonanza Creek site over seven different years. On this figure, the error bars represent the absolute differences between the geometric mean and its lower and upper limits. Winter months are absent, since these instruments are currently not run during the winter, when climate is rigorous and sunlight is weak. Despite the non-existence of systematic records for spring, the well-known aerosol load maximum of this season (Shaw and Khalil, 1989) occurred during this season in 1995, 1998, and 2000. (The maximum of the spring-to-fall period occurs in spring some years and in summer other years.) Note that observations for spring are lacking in 1994, 1996, and 1997. Significant interannual variation for each of the three seasons can also be noted. The year 1998, with a spring AOD500 value of about 0.15 , corresponds to the highest aerosol loading in Bonanza Creek between 1994 and 2000. A more comprehensive yearly coverage and a longer archival recording period (several decades) are needed to understand the global long-term trend of Arctic aerosol loading from observations of interannual variation. By monitoring monthly averages, we can derive a parameter's pattern for each month over a period of years, and this is another way to check climate variability induced by atmospheric aerosols and water vapour.

The seasonal mean Angstrom coefficient $(\alpha)$ trend reveals a peak that oscillates between summer and fall (Fig. 3), suggesting an increased concentration of smaller aerosol particles (sometimes referred to as Aitken particles) during these seasons, mostly in summer. In fact, the photolysis induced by the intense summer sunlight may play an important role in generating these particles. The summer (June, July, August) mean value over all the 1994-2000 record period is $1.50 \pm 0.56$; this value is typically in the range of Angstrom coefficient values obtained for continental or rural background conditions (Holben et al, 2000).

Figure 4 a shows the instantaneous volume size distribution (log-log scale) integrated over the atmospheric column in Bonanza Creek between 1994 and 2000. These distributions were inferred from the Dubovik and King (2000) algorithm, the validation of which is discussed in Bokoye et al. (2001). This distribution, limited to $15 \mu \mathrm{m}$ in diameter, is characterized by two accumulation modes around 0.2 and $2 \mu \mathrm{m}$ (modal values) that respectively represent submicron particles and coarse particles of several micrometers in diameter that contain the majority of particle mass. The coarse particles play an important role in the chemical process and interact with solar radiation (Bigg, 1980; Shaw, 1984).

Figure $4 \mathrm{~b}$ represents the mean volume size distribution from 1022 spectra in Bonanza Creek between 1994 and 2000. This distribution reveals the bimodality (fine and coarse modes) of aerosol particle distributions over $1994-$ 


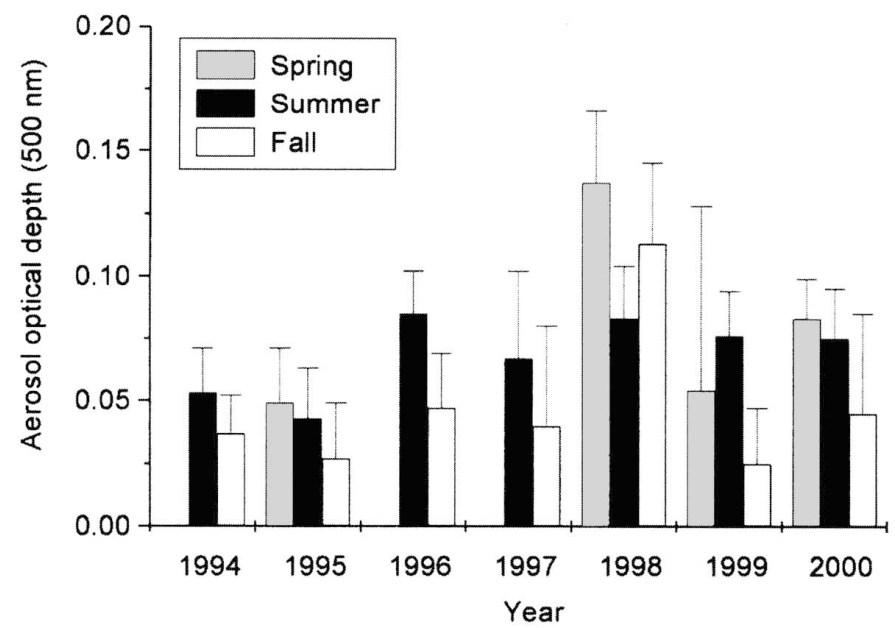

FIG. 2. Seasonal mean variation of aerosol optical depth at $500 \mathrm{~nm}$ (geometric mean) at the Bonanza Creek site, Alaska, during 1994-2000.

2000. Important variations in the standard deviations are due to year-to-year variations in aerosol density. The AERONET processing algorithm considers particles smaller than $0.6 \mu \mathrm{m}$ as "fine mode" and particles larger than $0.6 \mu \mathrm{m}$ as "coarse mode." This threshold is not always valid, but the AERONET experience indicates that it works in the majority of practical cases. The above definitions were used to evaluate the effective radius (in logarithmic scale) for fine and coarse mode for all the retrieved aerosol size distributions in Bonanza Creek (Fig. 4c). There was no significant interannual variation of the effective radius during 1994-2000. Table 3 summarizes the average values of this parameter from compiled instantaneous data (Fig. 4b) for June, July, and August, for summer, and over the total period of observations. If we take into consideration the relative importance of the number of observations over the seven years (1994-2000), these values can be considered as reference values for the Arctic continental areas.

Figure 5 shows a time series of the seasonal PWVC variation for each year from 1994 to 2000 . The year-toyear values show a systematic summer maximum and a slight global increasing trend. Typically, maximum summer values are between 1.25 and $2.25 \mathrm{~g} \mathrm{~cm}^{-2}$.

The summer average is $1.78 \pm 0.54 \mathrm{~g} \mathrm{~cm}^{-2}$, a value slightly superior to the summer zonal mean of about $1.2 \mathrm{~g} \mathrm{~cm}^{-2}$ from Serreze et al. (1995). This last study drew on an extensive archive of radiosonde data collected between 1974 and 1991 at $70^{\circ} \mathrm{N}$.

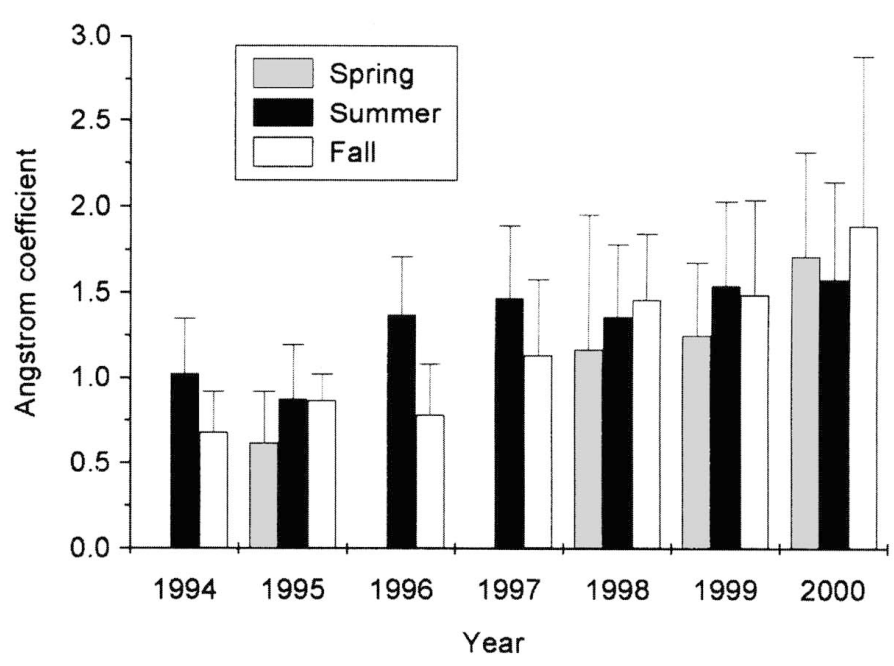

FIG. 3. Seasonal mean variation of Angstrom coefficient at the Bonanza Creek site, Alaska, 1994-2000.

The mean monthly values we reported for AOD500 (Table 4), $\alpha$ (Table 5), and PWVC (Table 6) can be used by the aerosol study community as references for Arctic regions. Table 7 shows the number of days and the number of observations corresponding to each month considered.

\section{Arctic Haze and Meteorological Conditions}

Climatically, the Arctic is often defined as the area north of the $10^{\circ} \mathrm{C} \mathrm{July} \mathrm{isotherm} \mathrm{(i.e.,} \mathrm{north} \mathrm{of} \mathrm{the} \mathrm{line} \mathrm{or}$ region that has a mean July temperature of $10^{\circ} \mathrm{C}$ ). Its meteorological system constitutes a key parameter in the seasonal haze cycle. The climate system, highly influenced by regional weather patterns and ocean currents, is characterized by the stagnant, polluted Arctic air mass, which consists of very cold continental air with little or no maritime influence. Polar air masses formed over Canada and the Gulf of Alaska are common wintertime intruders upon the continental limits. These masses are also accompanied by crisp, dry, cold air, but they are not as bitterly cold as the Arctic air mass. In winter, the Arctic air mass is nearly cloud-free, with very little or no solar radiation at a time in winter (Shaw and Khalil, 1995). In summer, the air mass is more turbulent and cloudy. The North American Arctic basin also undergoes the influence of northern Pacific air (the Pacific marine air mass), which is warmer and wetter than Arctic air. While the Pacific air is relatively clean, the Arctic air is persistently polluted (Arctic

TABLE 3. Average effective radius (in $\mu \mathrm{m}$ ) inferred from aerosol size distributions (fine and coarse modes) at the Bonanza Creek site, showing mean values for June, July, and August; for summer; and for the entire observation period (1994-2000).

\begin{tabular}{|c|c|c|c|c|c|c|c|c|c|c|}
\hline & \multicolumn{10}{|c|}{ Average effective radius (in $\mu \mathrm{m}$ ) from aerosol size distributions during 1994-2000 } \\
\hline & June & SD & July & SD & August & SD & Summer & SD & Total & SD \\
\hline Fine mode & 0.165 & 0.025 & 0.172 & 0.034 & 0.187 & 0.043 & 0.174 & 0.035 & 0.182 & 0.037 \\
\hline No. of Observations & \multicolumn{2}{|c|}{197} & \multicolumn{2}{|c|}{184} & \multicolumn{2}{|c|}{141} & \multicolumn{2}{|c|}{522} & \multicolumn{2}{|c|}{1022} \\
\hline
\end{tabular}



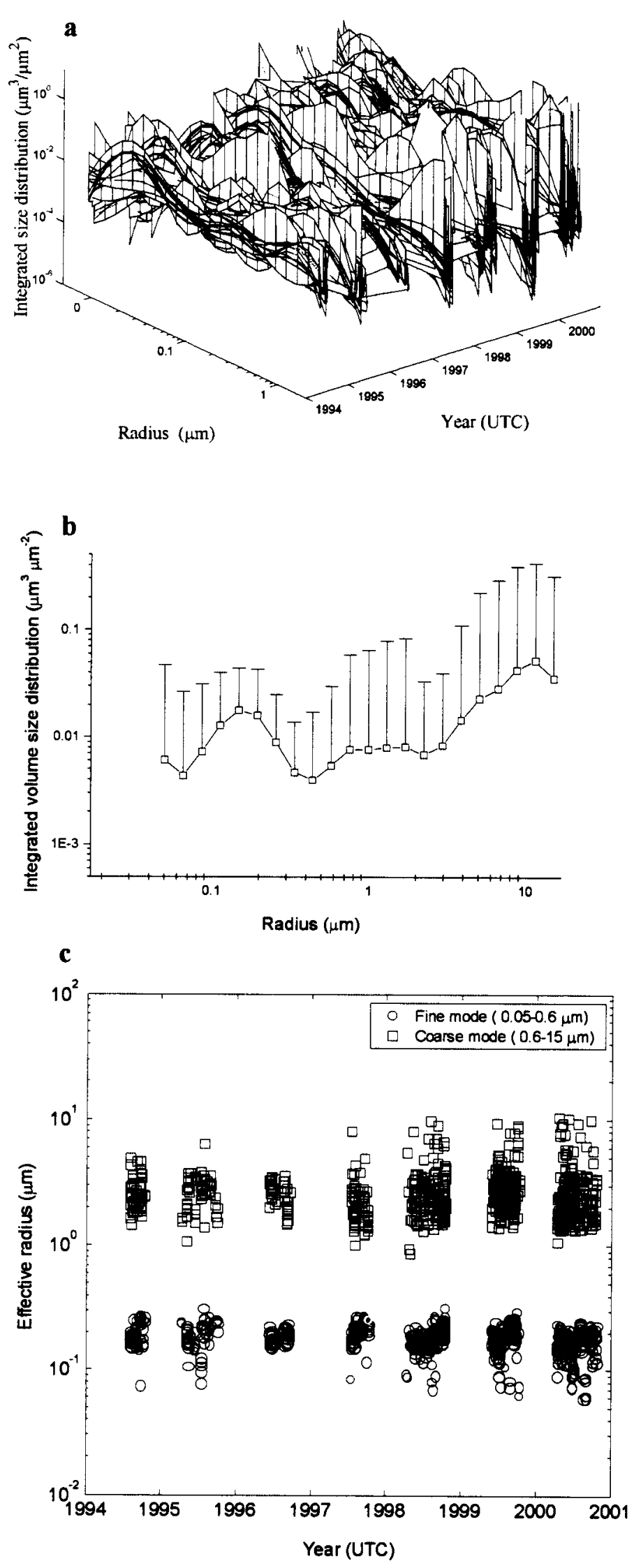

FIG. 4. Characteristics of aerosol size distribution at Bonanza Creek during 1994-2000. (a): integrated volume size distribution over a vertical atmospheric column; (b) mean volume size distribution; (c): time series of aerosol effective radius $(\mu \mathrm{m})$.

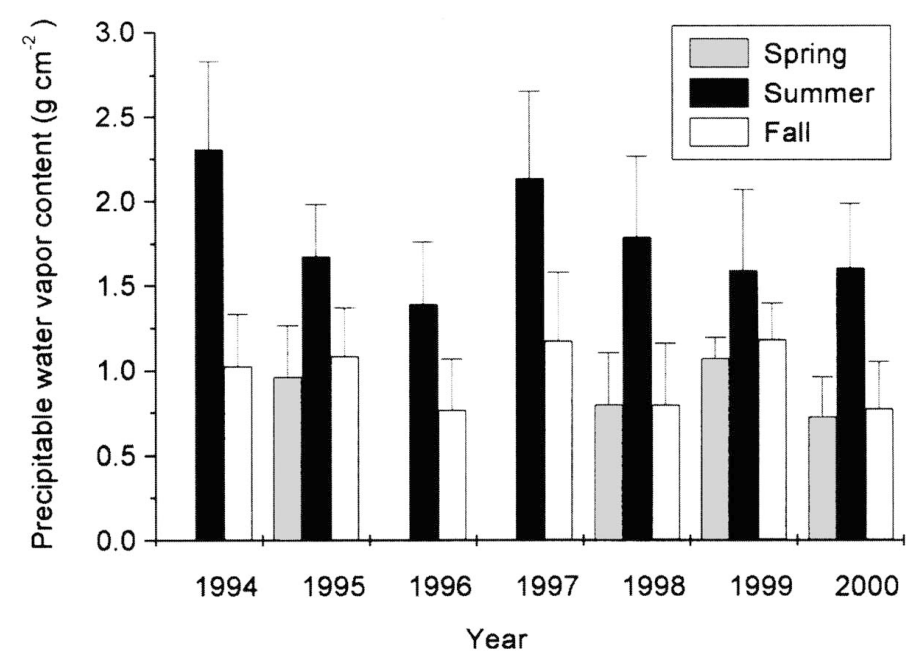

FIG. 5. Seasonal mean variation of precipitable water vapour content during 1994-2000 at Bonanza Creek site, Alaska.

haze), and visibility is usually reduced because of haze and smoke in the surface layers. Aerosols enter the Arctic via the man-made polluted flow of air extending northeastward from central Europe to northeastern central Eurasia in winter. The Arctic regions increasingly undergo humaninduced air pollution due to cumulative effects of Arctic industrialization, in particular oil expansion. The air mass is often dry and characterized by a high dynamic stability, since mechanisms (precipitation) that remove particles and gases are absent, notably in winter. The air front usually lowers high temperatures by $15-30$ degrees, with lows dropping by $20-40$ degrees. Clear skies, high atmospheric pressure, and low humidity (in continental zones in particular) prevail in winter and spring. Figure $6 \mathrm{a}$ highlights the remarkable stability of pressure profiles in Churchill. The surface pressures at ground level are high throughout the year, with values close to the standard pressure at sea level $(1013 \mathrm{mb})$. The relative humidity profiles in the same locality (Fig. 6b) show an increasing trend between the winter and the warm months. The relative humidity values at ground level are very large in Churchill. This can be linked to the important evaporation of water in the Hudson Bay basin that influences Churchill meteorology. In summer, the sunshine becomes more important, and the temperatures generally remain between $-10^{\circ}$ and $20^{\circ} \mathrm{C}$. The vertical structure of the atmosphere is characterized by strong temperature inversion (increase of the temperature with altitude) that is very marked in winter, as shown by temperature profiles for Churchill in 2000 (Fig. 6c). Figure 7 shows Churchill's mean atmospheric profiles of pressure (Fig. 7a), relative humidity (Fig. 7b), and temperature (Fig. 7c) from 231 radiosondes for the year 2000. Except for the temperature inversion between 0 and $1 \mathrm{~km}$ altitude, these profiles are characterized by a classical decrease with increasing altitude.

Figure 8 shows the variations of AOD500, the Angstrom coefficient $\alpha$, and PWVC in parallel to surface (about $30 \mathrm{~m}$ above the ground, corresponding to the first-level radio- 
TABLE 4. Monthly mean values of first-order AERONET/AEROCAN-derived aerosol optical depth at $500 \mathrm{~nm}$ at the Bonanza Creek site during 1994-2000.

\begin{tabular}{|c|c|c|c|c|c|c|c|c|c|c|c|c|c|c|}
\hline \multirow[b]{2}{*}{ MONTH } & \multicolumn{2}{|c|}{1994} & \multicolumn{2}{|c|}{1995} & \multicolumn{2}{|c|}{1996} & \multicolumn{2}{|c|}{1997} & \multicolumn{2}{|c|}{1998} & \multicolumn{2}{|c|}{1999} & \multicolumn{2}{|c|}{2000} \\
\hline & AOD500 & CI & AOD500 & $\mathrm{CI}$ & AOD500 & $\mathrm{CI}$ & AOD500 & $\mathrm{CI}$ & AOD500 & $\mathrm{CI}$ & AOD500 & $\mathrm{CI}$ & AOD500 & $\mathrm{CI}$ \\
\hline April & \multicolumn{8}{|c|}{$0.0390 .036-0.041$} & \multicolumn{2}{|c|}{$0.2070 .190-0.226$} & & & \multicolumn{2}{|c|}{$\begin{array}{lll}0.061 & 0.058-0.064\end{array}$} \\
\hline May & \multirow{2}{*}{\multicolumn{4}{|c|}{$\begin{array}{ll}0.054 & 0.050-0.058 \\
0.071 & 0.070-0.075\end{array}$}} & \multirow{2}{*}{\multicolumn{2}{|c|}{$0.0950 .090-0.100$}} & & & \multicolumn{2}{|c|}{$0.0950 .089-0.101$} & \multicolumn{2}{|c|}{$0.0540 .045-0.064$} & \multicolumn{2}{|c|}{$0.1050 .100-0.110$} \\
\hline June & & & & & & & \multirow{2}{*}{\multicolumn{2}{|c|}{$0.0670 .061-0.072$}} & \multicolumn{2}{|c|}{$0.0740 .069-0.079$} & \multicolumn{2}{|c|}{$0.0910 .087-0.095$} & \multicolumn{2}{|c|}{$0.0680 .065-0.070$} \\
\hline July & \multicolumn{2}{|c|}{$\begin{array}{ll}0.06 & 0.053-0.068 \\
0.05 & 0.046-0.054\end{array}$} & \multicolumn{2}{|c|}{$\begin{array}{ll}0.071 & 0.070-0.075 \\
0.037 & 0.034-0.040\end{array}$} & \multicolumn{2}{|c|}{$0.0950 .088-0.102$} & & & \multicolumn{2}{|c|}{$0.0860 .078-0.095$} & \multicolumn{2}{|c|}{$0.120 .113-0.127$} & \multicolumn{2}{|c|}{$0.1190 .104-0.136$} \\
\hline August & \multicolumn{2}{|c|}{$0.0540 .051-0.056$} & \multicolumn{2}{|c|}{$0.0310 .030-0.032$} & \multicolumn{2}{|c|}{$0.0630 .058-0.068$} & \multicolumn{2}{|c|}{$0.0640 .048-0.084$} & \multicolumn{2}{|c|}{$0.0920 .085-0.100$} & \multicolumn{2}{|c|}{$\begin{array}{lll}0.031 & 0.029-0.032\end{array}$} & \multicolumn{2}{|c|}{$0.0520 .045-0.060$} \\
\hline September & 0.0380 .0 & $36-0.040$ & \multirow{2}{*}{\multicolumn{2}{|c|}{$0.0270 .026-0.028$}} & \multirow{2}{*}{\multicolumn{2}{|c|}{$0.0470 .045-0.050$}} & \multirow{2}{*}{\multicolumn{2}{|c|}{$\begin{array}{ll}0.039 & 0.034-0.043 \\
0.043 & 0.037-0.049\end{array}$}} & $0.08 \quad 0.0$ & $72-0.088$ & 0.0240 .0 & $22-0.025$ & $0.057 \quad 0.0$ & $48-0.067$ \\
\hline October & \multicolumn{2}{|c|}{$0.0340 .031-0.037$} & & & & & & & 0.1510 .1 & $37-0.165$ & $0.04 \quad 0.0$ & $33-0.048$ & $0.038 \quad 0.0$ & $35-0.041$ \\
\hline Year & 0.0450 .0 & $43-0.046$ & 0.0430 .0 & $41-0.044$ & 0.0750 .0 & $72-0.077$ & 0.0620 .0 & $58-0.066$ & 0.1070 .1 & $03-0.111$ & $0.06 \quad 0.0$ & $58-0.062$ & 0.0740 .0 & $58-0.093$ \\
\hline
\end{tabular}

TABLE 5. Monthly mean values of first-order AERONET/AEROCAN-derived Angstrom coefficient $(\alpha)$ at the Bonanza Creek site during 1994-2000.

\begin{tabular}{|c|c|c|c|c|c|c|c|c|c|c|c|c|c|c|}
\hline \multirow[b]{2}{*}{ MONTH } & \multicolumn{2}{|c|}{1994} & \multicolumn{2}{|c|}{1995} & \multicolumn{2}{|c|}{1996} & \multicolumn{2}{|c|}{1997} & \multicolumn{2}{|c|}{1998} & \multicolumn{2}{|c|}{1999} & \multicolumn{2}{|c|}{2000} \\
\hline & $\alpha$ & SD & $\alpha$ & SD & $\alpha$ & $\mathrm{SD}$ & $\alpha$ & SD & $\alpha$ & SD & $\alpha$ & SD & $\alpha$ & $\mathrm{SD}$ \\
\hline April & & & 0.411 & 0.158 & & & & & 1.097 & 1.067 & & & 1.649 & 0.702 \\
\hline May & & & 0.716 & 0.308 & & & & & 1.229 & 0.391 & & & 1.757 & 0.512 \\
\hline June & 1.427 & 0.286 & 0.611 & 0.206 & 1.376 & 0.33 & & & 1.605 & 0.311 & 1.427 & 0.286 & 1.616 & 0.544 \\
\hline July & 0.969 & 0.362 & 0.966 & 0.353 & 1.37 & 0.329 & 1.482 & 0.423 & 1.291 & 0.429 & 0.969 & 0.362 & 1.616 & 0.567 \\
\hline August & 1.004 & 0.287 & 1.01 & 0.208 & 1.361 & 0.363 & 1.379 & 0.411 & 1.049 & 0.320 & 1.004 & 0.2879 & 1.3 & 0.604 \\
\hline September & 0.702 & 0.245 & 0.867 & 0.152 & 0.783 & 0.296 & 0.979 & 0.388 & 1.333 & 0.353 & 0.702 & 0.245 & 1.529 & 0.956 \\
\hline October & 0.561 & 0.156 & & & & & 1.552 & 0.27 & 1.571 & 0.373 & 0.561 & 0.156 & 2.179 & 0.92 \\
\hline Year & 0.857 & 0.331 & 0.781 & 0.323 & 1.242 & 0.409 & 1.415 & 0.44 & 1.332 & 0.563 & 0.857 & 0.331 & 1.672 & 0.649 \\
\hline
\end{tabular}

sonde) meteorological parameters: the ambient temperature $\left({ }^{\circ} \mathrm{C}\right)$, the pressure $(\mathrm{mb})$, and the relative humidity. There is no apparent link between these meteorological parameters and AOD500 or $\alpha$. The PWVC time series is well correlated to those of temperature. In fact, it is well known that an increase in ambient temperature generally leads to increased water vapour in the atmosphere.

\section{DISCUSSION}

A more thorough analysis, coupled with a more extensive database, is required to relate the optical data of the type described in this paper to climate variations. This analysis should include standard techniques to assess the correlation between the measured optical depth and groundbased meteorological data, as well as investigations into the chemical constituents of specific aerosol species. As an example of the first type of analysis, the 1998 data, which show an apparently uncommon AOD seasonal profile, correspond to the warmest year on record (the corresponding temperature average was $2.5^{\circ} \mathrm{C}$ above the 30 -year normal in Canada, according to the Canadian meteorological office). Areas of the Arctic registered annual temperatures more than $4^{\circ} \mathrm{C}$ above normal in 1998.

The year-to-year seasonal and monthly AOD500 values revealed a more marked variability compared to that of the Angstrom coefficient. In fact, AOD is linked to aerosol density in the vertical atmospheric column. Its value can vary significantly over time according to the aerosol flow from emission sources, either natural or anthropogenic.
The $\alpha$ parameter is linked to aerosol size. For a given season, approximately the same class of particle in size $\alpha$ value can be retrieved independently of their concentration, taking into account the cyclic nature of the Arctic haze process during the year. This explains the relative year-to-year stability of the fine and coarse effective radii at the Bonanza Creek site (Table 3).

Aerosol characteristics depend upon a number of chemical species whose concentration in the Arctic region can vary significantly during the year. According to Jaffrezo et al. (1999), brief episodes of high airborne concentrations traceable to a variety of sources can occur in the Arctic. These sources include soil dust, sea spray, biomass burning, anthropogenic industrial inputs, and biological productivity in the ocean. Note that the haze is generally spatially uniform over scales larger than hundreds of kilometres, and it is primarily confined to the lower $2-4 \mathrm{~km}$ of the atmosphere (Shaw and Khalil, 1989).

The observations presented in this paper show the potential of the AERONET/AEROCAN database for generating a new aerosol climatology (more than 12000 observations at Waskesiu since 1994 and about 28000 for northern Canada and Alaska). The extension of the AERONET/ AEROCAN network to new Arctic or Subarctic sites is an important goal for the network if we are to understand and fully assess the spatial and temporal distribution of Arctic aerosol properties over the long term (several decades). The current aerosol optical properties database can be used as a framework for building a mean aerosol climatology over a decade. In fact, the year-to-year, season-to-season analysis of derived parameters allows us to check the 

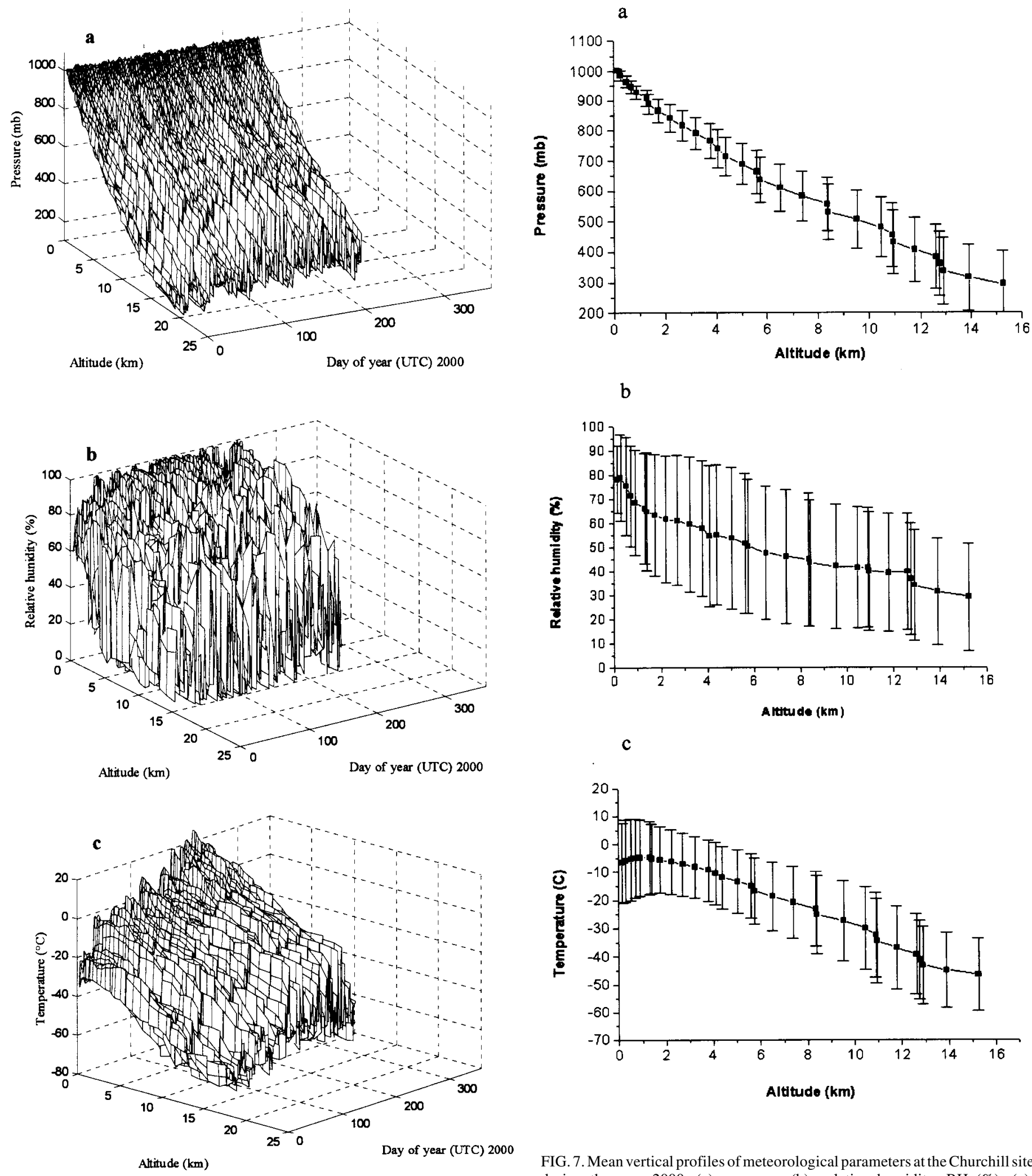

FIG. 6. Time series of vertical profiles of meteorological parameters at the Churchill site during the year 2000. (a): pressure; (b): relative humidity, RH $(\%)$; (c): temperature $\left({ }^{\circ} \mathrm{C}\right)$.

FIG. 7. Mean vertical profiles of meteorological parameters at the Churchill site during the year 2000. (a): pressure, (b): relative humidity, RH (\%); (c): temperature $\left({ }^{\circ} \mathrm{C}\right)$.

changes in Arctic climate due to atmospheric aerosols. The database is also useful to validate aerosol parameters from satellite observations in the Arctic regions.

The recent installation of an AEROCAN sunphotometer at the Churchill Northern Study Centre (CNSC) is a first 
TABLE 6. Monthly mean values of first-order AERONET/AEROCAN-derived precipitable water vapour content (PWVC) in $\mathrm{g} \mathrm{cm}^{-2}$ at the Bonanza Creek site during 1994-2000.

\begin{tabular}{|c|c|c|c|c|c|c|c|c|c|c|c|c|c|c|}
\hline \multirow[b]{2}{*}{ MONTH } & \multicolumn{2}{|c|}{1994} & \multicolumn{2}{|c|}{1995} & \multicolumn{2}{|c|}{1996} & \multicolumn{2}{|c|}{1997} & \multicolumn{2}{|c|}{1998} & \multicolumn{2}{|c|}{1999} & \multicolumn{2}{|c|}{2000} \\
\hline & PWVC & SD & PWVC & SD & PWVC & SD & PWVC & SD & PWVC & $\mathrm{SD}$ & PWVC & SD & PWVC & $\mathrm{SD}$ \\
\hline April & & & 0.718 & 0.062 & & & & & 0.616 & 0.205 & & & 0.715 & 0.2 \\
\hline May & & & 1.079 & 0.303 & & & & & 0.953 & 0.295 & 1.069 & 0.122 & 0.734 & 0.258 \\
\hline June & 1.697 & 0.163 & 1.672 & 0.298 & 1.322 & 0.254 & & & 1.78 & 0.469 & 1.421 & 0.442 & 1.556 & 0.312 \\
\hline July & 2.431 & 0.453 & 1.765 & 0.361 & 1.769 & 0.215 & 2.043 & 0.341 & 2.04 & 0.297 & 1.697 & 0.506 & 1.836 & 0.378 \\
\hline August & 2.334 & 0.522 & 1.593 & 0.238 & 1.08 & 0.329 & 2.634 & 0.889 & 1.522 & 0.503 & 1.765 & 0.395 & 1.408 & 0.488 \\
\hline September & 1.071 & 0.292 & 1.083 & 0.284 & 0.767 & 0.299 & 1.32 & 0.380 & 1.1 & 0.314 & 1.177 & 0.212 & 0.968 & 0.248 \\
\hline October & 0.756 & 0.26 & & & & & 0.776 & 0.017 & 0.529 & 0.099 & 1.25 & 0.237 & 0.625 & 0.194 \\
\hline Year & 1.682 & 0.774 & 1.353 & 0.458 & 1.253 & 0.441 & 1.993 & 0.608 & 1.154 & 0.618 & 1.493 & 0.466 & 1.126 & 0.534 \\
\hline
\end{tabular}

TABLE 7. Monthly distribution of sunphotometry observations during 1994-2000, showing number of observation days and total number of observations made in each month (April to October). Means in Tables 4, 5, and 6 are based on data from these same observations.

\begin{tabular}{|c|c|c|c|c|c|c|c|c|c|c|c|c|c|c|}
\hline \multirow[b]{2}{*}{ MONTH } & \multicolumn{2}{|r|}{1994} & \multicolumn{2}{|r|}{1995} & \multicolumn{2}{|r|}{1996} & \multicolumn{2}{|r|}{1997} & \multicolumn{2}{|r|}{1998} & \multicolumn{2}{|r|}{1999} & \multicolumn{2}{|r|}{2000} \\
\hline & Days & Observations & Days & Observations & Days & Observations & Days & Observations & Days & Observations & Days & Observations & Days & Observations \\
\hline April & & & 8 & 134 & & & & & 17 & 197 & & & 15 & 375 \\
\hline May & & & 22 & 278 & & & & & 22 & 224 & 5 & 46 & 27 & 517 \\
\hline June & 4 & 24 & 17 & 184 & 21 & 429 & & & 19 & 206 & 28 & 582 & 26 & 579 \\
\hline July & 12 & 63 & 20 & 197 & 24 & 278 & 14 & 195 & 19 & 151 & 21 & 400 & 24 & 219 \\
\hline August & 19 & 278 & 23 & 226 & 16 & 249 & 7 & 37 & 12 & 134 & 22 & 308 & 17 & 111 \\
\hline September & 23 & 295 & 12 & 120 & 12 & 267 & 8 & 30 & 15 & 211 & 24 & 313 & 20 & 98 \\
\hline October & 7 & 52 & & & & & 3 & 11 & 16 & 240 & 5 & 22 & 11 & 126 \\
\hline Year & 65 & 712 & 102 & 1139 & 73 & 1223 & 32 & 273 & 120 & 1363 & 105 & 1671 & 140 & 2025 \\
\hline
\end{tabular}

step in the direction of more systematic sampling of Arctic aerosols. This site, although outside the Arctic, will enable more frequent sampling of aerosols associated with Arctic air masses that migrate to lower latitudes.

\section{SUMMARY}

The ground-based automatic sunphotometer network permits long-term monitoring of aerosol optical properties and columnar water vapour content. This optical approach appears to be applicable in Arctic regions, as the results obtained at the AERONET Bonanza Creek site illustrate.

The AEROCAN network includes eight stations across Canada. Its most recent addition at Churchill began its monitoring program early in the summer of 2000. In spite of its sparse density, this network provides routine and robust temporal measurements of aerosol optical depth, which we are using to build a Canada-wide aerosol climatology. The latter will contribute to an improved understanding of global environmental change.

\section{ACKNOWLEDGEMENTS}

The authors are grateful to John R. Vande Castle (Department of Biology, University of New Mexico), the principal investigator of the Bonanza Creek AERONET site, for his authorization to use the data from this site. The authors also wish to thank the Natural Sciences and Engineering Research Council of Canada (NSERC), the Canadian Institute for Climate Studies (CICS), the Meteorological Service of
Canada (MSC) of Environment Canada, the Canada Centre for Remote Sensing (CCRS), the National Research Council of the National Academy of Sciences (U.S.A.), the National Aeronautics and Space Administration (NASA), the Quebec Fonds pour la Formation de Chercheurs et d'Aide à la Recherche (FCAR), the Manitoba Northern Research Fund Program, and the Churchill Northern Studies Centre (CNSC) for their contributions to the AEROCAN project. We are grateful to P.M. Teillet, G. Fedosejevs, and J. Freemantle for their help in the framework of AEROCAN activities.

\section{REFERENCES}

AGU (AMERICAN GEOPHYSICALUNION). Drafting Statement on Climate Change. 1998. Alpine glaciers continue to melt. Science update-Length of melt season supports Arctic warming trend. Greenland ice sheet data inconclusive. Global Environment Change Report 6(10).

BARRIE, L.A. 1986. Arctic air pollution monitoring: An overview of current knowledge. Atmospheric-Environment 15(20): 643-663.

BARRIE, L.A., and BLANCHET, J-P. 1996. Aerosols and climate: Northern Aerosol Regional Climatic Model (NARCM): A collaborative proposal to the Canadian Climate Research Program. Available from the Meteorological Service of Canada, Environment Canada, 4905 Dufferin St., Downsview, Ontario M3H 5T4, Canada.

BECKER, E., NOTHOLT, J., and HERBER, A. 1999. Tropospheric aerosol measurements in the Arctic by FTIR-emission and star photometer extinction spectroscopy. Geophysical Research Letters 26(12):1711-1714. 

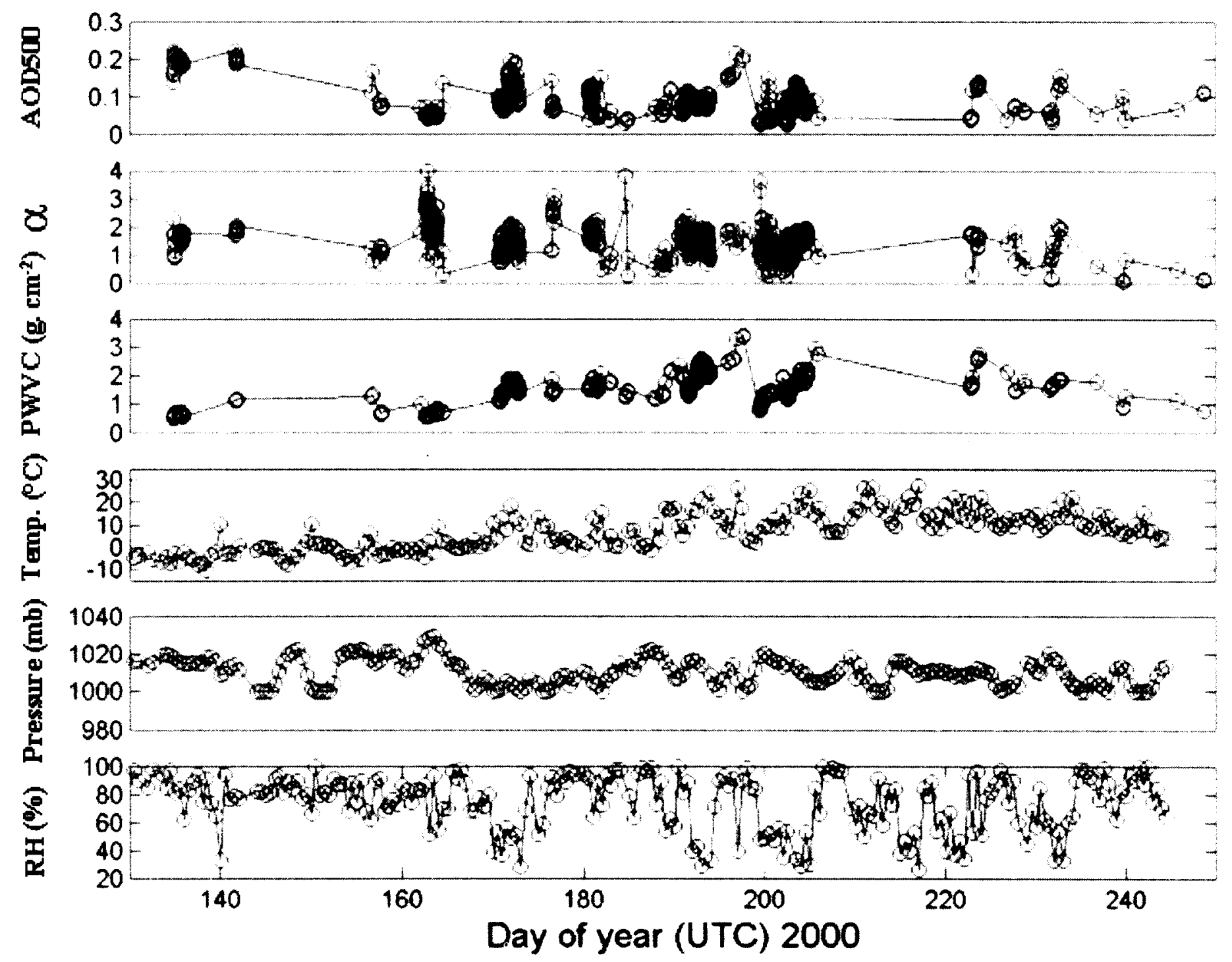

FIG. 8. AERONET/AEROCAN-derived parameters (aerosol optical depth at $500 \mathrm{~nm}$, Angstrom coefficient $\alpha$, and precipitable water vapour content [g cm-2]) in connection with classical surface meteorological parameters (temperature $\left[{ }^{\circ} \mathrm{C}\right]$, pressure in millibars, and relative humidity $[\mathrm{RH}]$ in $\%$ ) at the Churchill site during the year 2000 .

BIGELOW, D.S., and SLUSSER, J.R. 2000. Establishing the stability of multi-filter UV rotating shadowband radiometers. Journal of Geophysical Research 105(D4):4833-4840.

BIGG, E.K. 1980. Comparison of aerosol at four baseline atmospheric monitoring stations. Journal of Applied Meteorology 19:521-533.

BLANCHET, J.-P. 1989. Toward the estimation of climatic effects due to Arctic aerosols. Atmospheric-Environment 23:2609-2625.

- 1991. Potential climate change from Arctic air pollution. In: Sturges, W.T., ed. Pollution of the Arctic atmosphere. London. Elsevier Press. 289-322.

BLANCHET, J.-P., and GIRARD, E. 1994. Arctic greenhouse effect. Nature 371:383.

BOKOYE, A.I., ROYER, A., O’NEILL, N.T., FEDOSEJEVS, G., TEILLET, P.M., McARTHER, L.J.B., and CLICHE, P. 2001. Characterization of atmospheric aerosols across Canada from a ground-based sunphotometer network: AEROCAN. Atmosphere-Ocean 39(4):429-456.
CARLSON, T.N. 1981. Speculations on the movement of polluted air to the Arctic. Atmospheric-Environment 15:1473-1477.

DUBOVIK, O., and KING, M.D. 2000. A flexible inversion algorithm for retrieval of aerosol optical properties from sun and sky radiance measurements. Journal of Geophysical Research 105:20673-20696.

DUBOVIK, O., SMIRNOV, A., HOLBEN, B.N., KING, M.D., KAUFAM, Y.J., ECK, T.F., and SLUTSKER, I. 2000. Accuracy assessments of aerosol optical properties retrieved from AERONET sun and sky-radiance measurements. Journal of Geophysical Research 105:9791-9806.

ECK, T.F., HOLBEN, B.N., WARD, D.E., DUBOVIK, O., REID, J.S., SMIRNOV, A., MUKALABAI, M.M., HSU, N.C., O'NEILL, N.T., and SLUTSKER, I. Characterization of the optical properties of biomass burning aerosols in Zambia during 1997 ZIBBEE experiment. Journal of Geophysical Research 104(31):31333-31350. 
FORGAN, B. 1994. General method for calibrating sunphotometers. Applied Optics 33(21):4841-4850.

FREUND, J. 1983. Aerosol optical depth in the Canadian Arctic. Atmosphere-Ocean 21(2):158-167.

GERNANDT, H., HERBER, A., VON DER GATHEN, P., REX, M., RINKE, A., WESSEL, S., and KANETO, S. 1996. Variability of ozone and aerosols in the polar atmosphere. Memoirs of National Polar Research. Special Issue 51:189-215.

GUEYMARD, C. 1994. Analysis of monthly average atmospheric precipitable water and turbidity in Canada and northern United States. Solar Energy 53:57-71.

HALTHORE, R.N., ECK, T.F., HOLBEN, B.N., and MARKHAM, B. 1997. Sun photometric measurements of atmospheric water vapour column abundance in the $940 \mathrm{~nm}$ band. Journal of Geophysical Research 102:4343-4352.

HANSEN, A.D.A., and ROSEN, H. 1984. Vertical distributions of particulate carbon, sulfur, and bromine in the Arctic haze and comparison with ground-level measurements at Barrow, Alaska. Geophysical Research Letters 11:457-460.

HEINTZENBERG, J. 1989. Arctic haze: Air pollution in polar regions. Ambio 18:50-55.

HERBER, A., WENDISCH, M., LEITERER, U., and NOTHOLT, J. 1991. Measurements of the optical depth and retrieval of aerosol parameters in the polar regions. Journal of Aerosol Sciences 22(Suppl. 1):S415-S418.

HERBER, A., THOMASON, L.W., DETHLOFF, K., VITERBO, P., RADIONOV, V.F., and LEITERER, U. 1996. Volcanic perturbation of the atmosphere in both polar regions 1991-1994. Journal of Geophysical Research 101(D2):3921-3928.

HERBER, A., DEBATIN, S., GRAESER, J., GERNANDT, H., SCHULZ, K.-H., NAEBERT, A., GANDERMANN, J., and ALEKSEEVA, G. 1997. Measurements of the spectral optical depth of aerosols with moon and star light during polar night 1994/95 and 1995/96 in Ny-Ålesund, Spitsbergen, Proceedings of the International Radiation Symposium 1996. In: Smith, W.L., and Stamnes, K., eds. Current problems in atmospheric radiation. Hampton, Virginia: Deepak Publ. $19-22$.

HOFF, R.M. 1988. Vertical structure of Artic haze observed by Lidar. Journal of Applied Meteorology 27:125-139.

HOFF, R.M., LEAITCH, W.R., FELLIN, P., and BARRIE, L.A. 1983. Mass size distributions of chemical constituents of the winter Arctic aerosol. Geophysical Research Letters 11: $381-384$.

HOLBEN, B.N., ECK, T.F., SLUTSKER, I., TANRÉ, D., BUIS, J.P., SETZER, A., VERMOTE, E., REAGAN, J.A., KAUFMAN, Y.J., NAKAJIMA, T., LAVENU, F., JANKOWIAK, I., and SMIRNOV, A. 1998. AERONET - a federated instrument network and data archive for aerosol characterization. Remote Sensing of the Environment 66:1-16.

HOLBEN, B.N., TANRÉ, D., SMIRNOV, A., ECK, T.F., SLUTSKER, I., ABUHASSAN, N., NEWCOMB, W.W., SCHAFER, J., CHATENET, B., LAVENUE, F., KAUFMAN, Y.J., VANDE CASTLE, J., SETZER, A., MARKHAM, B., CLARK, D., FROUIN, R., HALTHORE, R., KARNIELI, A., O’NEILL, N.T., PIETRAS, C., PINKER, R.T., VOSS, K., and
ZIBORDI, G. 2000. An emerging ground-based aerosol climatology: Aerosol Optical Depth from AERONET. Journal of Geophysical Research 106:12067-12097.

HOLMGREN, B., SHAW, G.E., and WELLER, G.1974. Turbidity in the Arctic atmosphere. AIDJEX Bulletin 27:135-148.

IVERSEN, T. 1984. On the atmospheric transport of pollution to the Arctic. Geophysical Research Letters 11:457-460.

JAFFREZO, J.-L., DAVIDSON, C.I., KUHNS, H.D., and STRADER, R. 1999. Seasonal variations in aerosol chemical species on the Greenland ice sheet. Unpubl. ms. Available at Laboratoire de Glaciologie et Géophysique de l'Environnement, Université Joseph Fourier, 54 rue Molière, Saint Martin d'Hères 38402, France.

KAHL, J.D., CHARLEVOIX, D.J., ZAITSEVA, N.A., SCHNELL, R.C., and SERREZE, M. 1993. Absence of evidence for greenhouse warming over the Arctic Ocean in the past 40 years. Nature 361:335-337.

LEDLEY, T.S., and PFIRMAN, S. 1997. The impact of sedimentladen snow and sea ice in the Arctic on climate. Climatic Change 37(4):665.

LEITERER, U., WELLER, M., and HERBER, A. 1992. Global changes of aerosols-ground based monitoring of the optical thickness in polar regions and central Europe. Berichte der Bunsengesellschaft für Physikalische Chemie 96(3):377-380.

McGUFFIE, K., COGLEY, J.G., and HENDERSON-SELLERS, A. 1985. Climatological analysis of Arctic aerosol quantity and optical properties at Resolute, N.W.T. Atmospheric-Environment 19(5):707-714.

MARKHAM, B.L., SCHAFER, J.S., HOLBEN, B.N., and HALTHORE, R.N. 1997. Atmospheric aerosol and water vapour characteristics over north central Canada during BOREAS. Journal of Geophysical Research 102:29737-29745.

MITCHELL, J.M., Jr. 1957. Visual range in the polar regions with particular reference to the Alaskan Arctic. Journal of Atmospheric and Terrestrial Physics (Special Supplement): 195-211.

NAGEL, D. , HERBER, A., THOMASON, L., and LEITERER, U. 1998. Vertical distribution of the spectral optical depth observation in the Arctic from 1993 to 1996. Journal of Geophysical Research 103(D2):1857-1870.

O'NEILL, N.T., IGNATOV, A., HOLBEN, B.N., and ECK, T.F. 2000. The lognormal distribution as a reference for reporting aerosol optical depth statistics: Empirical tests using multi-year, multi-site AERONET sunphotometer data. Geophysical Research Letters 27(20):3333-3336.

O'NEILL, N.T., ECK, T.F., HOLBEN, B.N., SMIRNOV, A., DUBOVIK, O., and ROYER, A. 2001. Bimodal size distribution influences on the variation of Angstrom derivatives in spectral and optical depth space. Journal of Geophysical Research 106:9787-9806.

OVERPECK, J., HUGHEN, K., HARDY, D., BRADLEY, R., CASE, R., DOUGLAS, M., FINNEY, B., GAJEWSKI, K., JACOBY, G., JENNINGS, A., LAMOUREAUX, S., LASCA, A., MACDONALD, G., MOORE, J., RETELLE, M., SMITH, S., WOLFE, A., and ZIELINSKI, G. 1997. Arctic environmental change of the last four centuries. Science 278:1251-1256.

PORTER, J.N., MILLER, M., PIETRAS, C., and MOTELL, C. 2000. Ship based sunphotometer measurements using 
MICROTOPS sunphotometers. Journal of Atmospheric and Oceanic Technology 18(5):765-774.

READER, M.C., and BOER, G.J. 1998. The modification of greenhouse gas warming by the direct effect of sulphate aerosols. Climatic Dynamics 14(7):593-607.

REAGAN, J.A., THOMASON, L.W., HERMAN, B.M., and PALMER, J.M. 1986. Assessment of atmospheric limitations on the determination of the solar spectral constant from groundbased spectroradiometer measurements. IEEE Transactions on Geoscience and Remote Sensing 24:258-266.

RUSSELL, P.B., LIVINGSTON, J.M., DUTTON, E.G., PUESCHEL, R.F., REAGAN, J.A., DEFOOR, T.E., BOX, M.A., ALLEN, D., PILEWSKIE, P., HERMAN, B.M., KINNE, S.A., and HOFMANN, D.J. 1993. Pinatubo and pre-Pinatubo optical-depth spectra: Mauna Loa measurements, comparisons, inferred particle size distributions, radiative effects and relationship to lidar data. Journal of Geophysical Research 98(D12):22969-22985.

SCHNELL, R.C., and RAATZ, W.E. 1984. Vertical and horizontal characteristics of Arctic haze during AGASP: Alaskan Arctic. Geophysical Research Letters 11:369-372.

SCHMID, B., and WEHRLI, C. 1995. Comparison of sunphotometer calibration by use of the Langley technique and the standard lamp. Applied Optics 34(21):4500-4512.

SCHMID, B., THOME, K.J., DEMOULIN, P., PETER, R., MÄTZLER, C., and SEKLER, J. 1996. Comparison of modeled and empirical approaches for retrieving columnar water vapour from solar transmittance measurements in the $0.94-\mu \mathrm{m}$ region. Journal of Geophysical Research 101(D5):9345-9358.

SCHMID, B., SPYAK, P.R., BIGGAR, S.F., WEHRLI, C., SEKLER, J., INGOLD, T., MÄTZLER, C., and KAMPFER, N. 1998. Evaluation of the applicability of solar and lamp radiometric calibrations of a precision Sun photometer operating between 300 and 1025 nm. Applied Optics 37:3923-3941.

SCHMID, B., MICHALSKY, J., HALTHORE, R., BEAUHARNOIS, M., HARISSON, L., LIVINGSTON, J., RUSSELl, P., HOLBEN, B., ECK, T., and SMIRNOV, A. 1999. Comparison of aerosol optical depth from four solar radiometers during the fall 1997 ARM intensive observation period. Geophysical Research Letters (26):2725-2728.

SERREZE, M.C., BARRY, R.G., and WALSH, J.E. 1995. Atmospheric water vapour characteristics at $70^{\circ} \mathrm{N}$. Journal of Climate 8(4):719-731.

SHAW, G.E. 1975a. Observations of two stratospheric dust events. Journal of Applied Meteorology 14:1614-1620.
. 1975b. The vertical distribution of atmospheric aerosols at Barrow, Alaska. Tellus 27:39-50.

1976. Properties of the background aerosols and their effects on climate. Science 192:1334-1336.

1981. Eddy diffusion transport of Arctic pollution from the mid latitudes: A preliminary model. Atmospheric-Environment 15:1483-1490.

1982. Atmospheric turbidity in the polar regions. Journal of Applied Meteorology 21:1080-1088.

- 1983. On the aerosol particle size distribution spectrum in Alaska air mass systems: Arctic haze and non-haze episodes. Journal of Atmospheric Science 40:1313-1320.

—_ 1984. Microparticle size spectrum of Arctic haze. Geophysical Research Letters 11:409-412.

SHAW, G.E., and KHALIL, M.A.K. 1989. Arctic haze. In: Huntziger, O., and Springer V., eds. The handbook of environmental chemistry. Vol. 4, Part B. Berlin: SpringerVerlag. 70-111.

SLUSSER, J., GIBSON, J., BIGELOW, D., KOLINSKI, D., DISTERHOFT, P., LANTZ, K., and BEAUBIEN, A. 2000. Langley method of calibrating UV filter radiometers. Journal of Geophysical Research 105(D4):4841-4849.

SMIRNOV, A., O'NEILL, N.T., ROYER, A., and TARUSSOV, A. 1996. Aerosol optical depth over Canada and the link with synoptical air mass types. Journal of Geophysical Research 101(D14):19299-19318.

SMIRNOV, A., HOLBEN, B.N., ECK, T.F., DUBOVIK, O., and SLUTSKER, I. 2000. Cloud screening and quality control algorithms for the AERONET data base. Remote Sensing of the Environment 73:337-349.

SOUFFLET, V., DEVAUX, C., and TANRÉ, D. 1992 . Modified Langley plot method for measuring the spectral aerosol optical thickness and its daily variations. Applied Optics 31(12): 2154-2161.

STONEHOUSE, B. 1986. Arctic air pollution. New York: Cambridge University Press.

TYSON, P. 1990. Hazing the Arctic. Earthwatch 10 (1):10-90.

WELLER, M., SCHULZ, E., LEITERER, U., NAEBERT, T., HERBER, A., and THOMASON, W. 1998. Ten years of aerosol optical depth observation at the Lindenberg Meteorological Observatory. Contribution to Atmospheric Physics 71(4): $387-400$.

WESSEL, S., AOKI, S., WELLER, R., HERBER, A., GERNANDT, H., and SCHREMS, O. 1997. Aerosol and ozone observations in the polar troposphere at Spitsbergen in spring 1994. Atmospheric Research 44:175-189. 